\title{
EMANCYPANTKI?
}

\section{ARTYSTKI POLSKIE W PARYŻU NA PRZELOMIE XIX I XX WIEKU}

\author{
Ewa BOBROWSKA (Paryż)
}

W 1913 roku Wacław Gąsiorowski, pisarz, wybitna postać polskiej kolonii artystycznej we Francji, opublikował na łamach warszawskiego „Tygodnika Ilustrowanego” alarmujący artykuł zatytułowany Emigracja intelektualna ${ }^{1}$. Wobec zatrważającego, jego zdaniem, zjawiska opuszczania ziem polskich przez intelektualistów autor przeprowadził trwającą ponad rok ankietę $\mathrm{w}$ kręgach emigracyjnych Paryża. $\mathrm{Z}$ zebranych przez niego danych wynikało, że w 1913 roku przebywało w Paryżu 299 polskich artystów, w tym około 80 kobiet. Sześćdziesiąt osiem spośród tych ostatnich uprawiało malarstwo, a dziesięć rzeźbę. Do tej liczby dodać trzeba pewną część pokaźnej, bo liczącej około pięciuset osób, rzeszy studentów. Według nowszych badań2 ${ }^{2}$, w latach 1890-1918 odbyło krótszy lub dłuższy pobyt w Paryżu około 160 polskich artystek. Stanowi to blisko jedną czwartą wszystkich polskich twórców, których pobyt w stolicy Francji udało się w tym okresie odnotować. Wartości te potwierdzają wyniki uzyskane przez Wacława Gąsiorowskiego ${ }^{3}$. W okresie, kiedy kariera zawodowa artystek nie była jeszcze

${ }^{1}$ W. Gąsiorowski, Emigracja intelektualna, Tygodnik Ilustrowany 1913 nr 16, s. 306; nr 17, s. $325-326$.

2 Dane te oparte są na informacjach, zgromadzonych przeze mnie w leksykonie artystów polskich, czynnych w Paryżu w latach 1890-1918, będącym częścią mojej rozprawy doktorskiej „Les artistes polonais en France 1890-1918. Communautés et individualités”, Université Paris I, 2001. Leksykon ten stale uzupełniam i aktualizuję (wersja aktualizowana w posiadaniu autorki). Dane te potwierdzają inne publikacje, jak np. H. Bartnicka-Górska i J. Szczepińska-Tramer, W poszukiwaniu światta, ksztattu i barw. Artyści polscy wystawiajacy na salonach paryskich w latach 1884-1960, Warszawa 2005, s. 17, a także strony adresowe w Roczniku Towarzystwa Polskiego Literackiego-Artystycznego, Paryż 1911.

${ }^{3}$ H. C. White, C. A. White, La carrière des peintres au XIXe siècle. Du système académique au marché des impressionnistes, Paris 1991 szacują liczbę kobiet malarek we Francji na podstawie ich udziału $\mathrm{w}$ salonach paryskich na jedna trzecią liczby wszystkich artystów. Wynika z tego, że udział Polek był nieco mniejszy niż średnia obliczona dla artystów różnych narodowości. Porównanie ilościowe według narodowości byłoby zresztą bardzo interesujące. 
społecznie ani oczywista, ani zaakceptowana, i wymagała od wybierających ją kobiet uporu i przezwyciężenia oporu rodziny i społecznych tabu, była to liczba bardzo istotna.

Przyczyn, dla których na przełomie XIX i XX wieku Paryż stał się artystyczną stolicą Polaków, było wiele ${ }^{4}$. Miasto było gościnne dla nękanych polityką zaborców polskich uchodźców politycznych i oferowało im nie tylko schronienie, ale także względną swobodę działań politycznych i kultywowania tożsamości narodowej. Pomimo przegranej wojny z Prusami rozkwit ekonomiczny we Francji sprawiał, że Paryż stał się — dzięki intensywnie działającym galeriom i marszandom ${ }^{5}$ - światowym centrum handlu sztuką. Ville-lumière, artystyczna stolica ówczesnego świata odznaczała się niezwykle ożywioną i pobudzającą atmosferą intelektualną, bujnym życiem artystycznym, znaczonym coraz to innymi, nowymi trendami. Bogate kolekcje sztuki dawnej pozwalały nie tylko studiować techniki mistrzów, ale dawały także możliwości zarobkowania malowaniem kopii. Władze III Republiki sprzyjały rozwojowi sztuki, stwarzając jej szerokie możliwości wystawiennicze. Na przełomie XIX i XX wieku w Paryżu wciąż jeszcze najważniejsze były salony. Były one zarówno konsekracją kariery zawodowej, jak i platformą wymiany poglądów artystycznych, przeglądem panujących tendencji, stanowiąc równocześnie wielki, dysponujący doskonałą reklamą w postaci obszernych sprawozdań prasowych, sklep z dziełami sztuki, odwiedzany przez liczne rzesze zwiedzających. Paryż stał się również ważnym centrum kształcenia artystycznego. W odróżnieniu od Monachium jednak to nie prestiżowa Szkoła Sztuk Pięknych była jego najmocniejszym argumentem. Dostęp do niej był bowiem dla obcokrajowców utrudniony. Dobrze rozwinięty system szkół prywatnych, tzw. akademii, w liczbie ok. dwudziestu ${ }^{6}$, otwartych dla cudzoziemców, zapewniał rzetelne i przystępne w cenie nauczanie ${ }^{7}$.

Trudna pod koniec XIX wieku zarówno z powodów politycznych, jak i ekonomicznych sytuacja artysty w Polsce w okresie zaborów została już dokładnie zanalizowana gdzie indziej ${ }^{8}$. Dla kobiet podejmujących karierę artystyczną była ona jeszcze trudniejsza. Dostęp do wyższego wykształcenia artystycznego był dla nich kluczowy. Jak podkreśla pionierka badań nad historią sztuki kobiet, Linda Nochlin w swoim fundamentalnym tekście Why Have There Been No Great Women Artists? ? $^{9}$, to właśnie brak instytucji, pozwalających zdobyć kobietom odpowiednie narzędzia do uprawiania zawodu na równi z mężczyznami, był ich najważniejszym handicapem. Jedyna na ziemiach polskich wyższa szkoła artystyczna w Krakowie oficjalnie została otwarta dla kobiet w 1914 roku, a pierwsze studentki przyjęła w 1920 roku $^{10}$. W Warszawie dostępna zarówno dla mężczyzn, jak i dla kobiet Szkoła Sztuk Pięknych zaczęła działać w 1904 roku. Wypełnić tę

\footnotetext{
${ }^{4}$ Por.: E. Bobrowska-Jakubowska, Artyści polscy we Francji. Wspólnoty i indywidualności, Warszawa 2004.

${ }^{5}$ Już w latach 60. XIX wieku Paul Durand-Ruel wprowadził nową koncepcję handlu sztuką. Po roku 1880 pojawiają się w Paryżu liczne nowe galerie i marszandzi, m.in. Georges Petit (1881), Ambroise Vollard (1894), a następnie Berthe Weil, Chéron, Bernheimowie, Paul Guillaume, Georges Thomas, Druet, Kahnweiler. W okresie pierwszej wojny światowej rozpoczął swoja działalność Leopold Zborowski.

${ }^{6}$ Pierwszą z nich była tzw. Académie Suisse, założona przez byłego modela w okresie Restauracji (wśród której uczniów byli m.in. Ingres, Courbet, Cézanne), a następnie Académie Charpentier, Colarossi, Académie des Champs-Elysées, Vitti, Délecluse, Grande Chaumière, Ranson i inne.

${ }^{7}$ G. Monnier, L'art et ses institutions en France. De la Révolution à nos jours, Paris 1995, s. 72.

${ }^{8}$ Por. np.: E. Bobrowska-Jakubowska, Artyści polscy we Francji.

${ }^{9}$ L. Nochlin, Why Have There Been No Great Women Artists?, Art News 1971 nr 69, s. 22-39.

${ }^{10}$ Por. listy studentów w: Materiały do dziejów Akademii Sztuk Pięknych w Krakowie, oprac. J. E. Dutkiewicz, J. Jeleniewska-Ślesińska, W. Ślesiński, Wrocław-Warszawa-Kraków 1969, s. 225-444.
} 
lukę próbowały szkoły prywatne, które zaczęto otwierać na ziemiach polskich od lat 90. XIX wieku. Niektórzy ich fundatorzy, a dokładniej fundatorki, jak Anna Bilińska-Bohdanowiczowa, Tola Certowicz, czy Maria Niedzielska, wykorzystywały w założonych przez siebie zakładach nabyte w Paryżu doświadczenia ${ }^{11}$. Ani jednak szkoły prywatne, ani prestiżowe i popularne krakowskie Wyższe Kursy dla Kobiet im. Adriana Baranieckiego $^{12}$, nie wykraczały poza średni poziom studiów.

Nie mogąc uzyskać odpowiedniego wykształcenia w kraju, młode polskie adeptki sztuki zaczęły wyjeżdżać za granicę, między innymi do Paryża. Choć Francuzki uzyskały czynne prawo wyborcze dopiero w 1944 roku, a Polki, którym historia powierzyła wyjątkową rolę „,matek” narodu i „Siłaczek”, odpowiedzialnych za jego przetrwanie, już w 1918, to jednak pod koniec XIX wieku Francja mogła przybyszkom znad Wisły zaoferować różne zdobycze ruchów feministycznych. Nie na darmo ruchy te początek swój wzięły w tendencjach filozoficznych francuskiego oświecenia. Już od 1803 roku we Francji kobiety mogły uczęszczać do szkół zawodowych, gdzie uczono rysunku do celów przemysłowych. Należała do nich np. bezpłatna Państwowa Szkoła Rysunku dla Dziewcząt (École nationale du dessin pour les jeunes filles), w której uczono dyscyplin dekoratorskich i użytkowych ${ }^{13}$, uznanych za odpowiednie dla temperamentu i charakteru kobiet, mających odznaczać się skromnością, cierpliwością i zdolnością do imitacji. Aż do lat 60. XIX wieku panująca we Francji ideologia nie pozwalała kobietom posługiwać się sztuką jako narzędziem do osiągnięcia sławy i zaspokojenia próżności, a tylko w celu zapewnienia „domowego szczęścia”. Wszelkie ambicje równorzędnej rywalizacji z mężczyznami w dziedzinie sztuk pięknych uznawano wręcz za groźne dla ustalonego porządku społecznego. $Z$ powodu społecznych i seksualnych tabu, a także ograniczeń instytucjonalnych, kobiety nie mogły w dostępnych dla nich szkołach państwowych uprawiać rysunku postaci ludzkiej z natury, a w szczególności studium aktu, będącego niezbędnym narzędziem akademickiej kompozycji i pracy nad najszlachetniejszym, według ówczesnej opinii, z gatunków - malarstwem historycznym ${ }^{14}$. Jednak już od połowy XIX wieku widoczne były osiągnięcia francuskich artystek, z Rosą Bonheur $^{15}$ na czele, w walce o prawa kobiet. Dzięki staraniom rzeźbiarki Hélène Bertaux (1825-1909), wystawiającej również pod nazwiskiem pani Leonowej Bertaux ${ }^{16}$,

${ }^{11}$ Np. otwarta w 1892 roku w Warszawie szkoła powracającej z Paryża Anny Bilińskiej-Bohdanowiczowej, czy szkoła Toli Certowiczówny otwarta w 1893 roku w Krakowie.

${ }^{12}$ Uczęszczały na nie artystki związane później z Paryżem, m.in.: Leona (Leonia) Bierkowska, malarka (1855-1925), Olga Boznańska (1865-1940), Janina Broniewska, rzeźbiarka, malarka (1886-1947), Maria z Kłopotowskich Chmielowska, malarka (1867-1929), Klementyna Mien, malarka (1870-1954), Jadwiga Gałęzowska (Malinowska-Gałęzowska), malarka (1876-1948), Helena Lustgarten-Ogrodzka, malarka (1876-1958), Blanka Mercère, malarka (1885-1937), Luna Drexler, rzeźbiarka (1882-1933), Maria Giżbert-Studnicka, malarka (1868-1955), Wanda Kossecka, malarka (1893-1955), Małgorzata Łada-Maciągowa, malarka (1881-1969), Matylda z Wodaków Meleniewska, malarka (1869-1930), Aniela Pająkówna, malarka (1864-1912), Eleonora Plutyńska, malarka (1886-1969), Irena z Serdów Zbigniewiczowa, malarka (1863-1954).

${ }^{13}$ Do dyscyplin tych należały m.in.: miniatura, ilustracja botaniczna, projektowanie porcelany, dywanów, wachlarzy, parawanów czy biżuterii.

${ }^{14}$ Por.: L. Nochlin, Why Have There Been, s. 22-39.

${ }^{15}$ Rosa Bonheur była pierwszą kobietą odznaczoną Legią Honorową za swoją pracę artystyczną w 1865 roku.

${ }^{16}$ Podkreślić należy, że artystka wystawiała pod takim właśnie nazwiskiem: pani Leonowa Bertaux, a nie jak pisze Joanna Sosnowska w swojej publikacji Poza kanonem: sztuka polskich artystek 1880-1939 (Warszawa 2003), jako Léon Bertaux, co sugerowałoby, że wystawiając używała tożsamości swego konkubenta, a później męża. Hélène Bertaux, choć aktywnie zaanga- 
studentki uzyskały formalnie wstęp do paryskiej Szkoły Sztuk Pięknych w 1897 roku $^{17}$, a od roku 1903 mogły stawać do konkursu Prix de Rome. Sama Bertaux już w 1873 otworzyła pierwszą prywatną pracownię rzeźby dla kobiet, a w 1881 roku założyła Związek Kobiet Malarek i Rzeźbiarek (Union des femmes peintres et sculpteurs), któremu przewodniczyła przez wiele lat. Również prywatne szkoły artystyczne zapewniały kobietom nowoczesne, takie same jak mężczyznom, metody kształcenia.

Założona w 1868 przez malarza Rodolphe'a Juliana prywatna szkoła artystyczna, tzw. akademia, oferowała tak wysoki poziom nauczania i profesorów takiej rangi, że przyciągała uczniów z całego świata. Około połowę studentów, w tym wiele kobiet, stanowili obcokrajowcy. Najliczniejsi wśród nich byli Amerykanie, a także Anglicy, Niemcy, Szwajcarzy, Austriacy, Skandynawowie oraz artyści z Europy Środkowej i Wschodniej. Wszyscy, bez względu na płeć, kształceni byli według tych samych metod, opartych na zaleceniach Ingresa, według których podstawą nauki był rysunek nagiego modela z natury. Podobnie jak w Szkole Sztuk Pięknych system nauczania opierał się na osobnych dla każdej z technik (malarstwo, rzeźba, rysunek) pracowniach, prowadzonych przez poszczególnych profesorów. W trosce o dobro moralne Julian odstąpił jednak od pierwotnego pomysłu pracowni koedukacyjnych i wprowadził osobne kursy dla kobiet i mężczyzn. Przez Akademię Julian przewinęło się na przestrzeni trzydziestu lat, od 1880 do pierwszej wojny światowej, około dziewięćdziesięciu Polaków, w tym mniej więcej dwadzieścia kobiet ${ }^{18}$. Polski kobiecy epizod na Akademii zainaugurowała Zofia Stankiewicz, która w 1880 r. zapisała się do pracowni Tony'go Robert-Fleury'ego. W 1882 roku wstąpiła tam polecona przez nią Anna Bilińska $^{19}$ oraz Tola Certowicz ${ }^{20}$, uczennica wspomnianej Hélène Bertaux i innego francuskiego rzeźbiarza, René de Saint-Marceaux. W 1884 dołączyła późniejsza działaczka feministyczna, Maria Dulębianka ${ }^{21}$, która studiowała u Tony'ego Roberta-Fleury'ego i Williama Bouguereau. Rok później wstąpiła tam zaprzyjaźniona z Bilińską Maria

żowana $\mathrm{w}$ walkę o prawa kobiet $\mathrm{w}$ dziedzinie sztuki, nie podawała się za mężczyznę, wystawiając pod męskim pseudonimem, jak sugeruje Sosnowska. Paradoksalnie, przyjęła tradycyjną we Francji (ale używaną również dawniej w Polsce) formę nazwiska kobiet zamężnych, w której to imię kobiety zastąpione jest imieniem jej małżonka. Przyjmując tę formę nazwiska kobieta traci niejako własną osobowość na korzyść męża. Wydaje się, że ten drobny fakt może zasadniczo zmienić interpretację działalności artystki na polu feminizmu, nie umniejszając przy tym jej zasług. W 1896 roku była ona jedyną kobietą członkiem jury rzeźby w Salonie Artystów Francuskich, a także pierwszą rzeźbiarką, która otrzymała złoty medal I klasy na Wystawie Światowej w 1889 roku.

${ }^{17}$ Praktycznie prawo to weszło w życie dopiero w 1900; por.: M. Sauer, L'entrée des femmes à l'Ecole des beaux-arts: 1880-1923, Paris 1990.

${ }^{18}$ Informacje na temat studiów Polek w Académie Julian zaczerpnięte są z ich biogramów opublikowanych w kolejnych tomach Słownika artystów polskich $i$ w Polsce działających, katalogów wystaw: C. Fehrer, The Julian Academy, Paris 1868-1939, New York 1989 oraz Overcoming All Obstacles: the Women of the Académie Julian, G. P. Weisberg, J. R. Becker [ed.], New York 1999; André Del Debbio Collection w Paryżu, księgi wpisów do Académie Julian „Catalogue général des élèves dames depuis 1868”, rkp. (dalej: „Catalogue général”).

${ }_{19}$ "Anna Bilińska-Bohdanowiczowa, malarka (1857-1893), studiowała malarstwo i rysunek na Akademii Julian u Tony'ego Roberta-Fleury'ego, J. J. Lefebvre'a i Williama Bouguereau; C. Fehrer, The Julian Academy.

${ }^{20}$ Tola (Teofila) Certowicz (Czertowicz), rzeźbiarka (1862-1918), studiowała rzeźbę na Akademii Julian u Antonina Mercié i Henri'ego Chapu w latach 1882-1893; C. Fehrer, The Julian Academy. Wg „Catalogue général” studiowała tam w latach1884-1889 w pracowni rzeźby.

${ }^{21}$ Maria Dulębianka, malarka (1861-1919) w latach 1884-1886 studiowała na Akademii Julian; C. Fehrer, The Julian Academy. 
Gażycz $^{22}$, która powróciła na Akademię w latach 1891-1895. W drugiej połowie lat 80. XIX wieku wśród studentek były Leona Bierkowska ${ }^{23}$, Aniela Poray-Biernacka ${ }^{24}$ i Drużbacka, oraz w 1889 r. Aniela Pająkówna. W następnym dziesięcioleciu uczęszczały tam Dziewanowska ${ }^{25}$, Matylda Meleniewska, Leokadia Łempicka ${ }^{26}$, Wanda Cichocka-Nałęcz $^{27}$, Stanisława Karłowska ${ }^{28}$, córka Wojciecha Gersona, Maria ${ }^{29}$, a ponoć także malarka Antonina Duninówna. W XX wieku kontynuowały naukę w Akademii Julian malarki: Anna Gramatyka ${ }^{30}$ (1901-1904), Zofia Lesman z domu Chylińska (ok. 1905), Irena Łuczyńska-Szymanowska i Michalina Tekla Nowicka-Kwiatkowska (1906), Małgorzata Ładówna (1906-1907), Blanka Mercère (1908) i Celina (Czesława?) Sunderland (1910-1914).

Studia w Akademii Julian zapewniały uczennicom nie tylko porady i korekty doświadczonych profesorów. Zachęcano je także do nieskrępowanej twórczości. W szkole panowała atmosfera absolutnej wolności artystycznej. Nawet regularnie organizowane konkursy, których celem było przygotowanie studentów do udziału w konkursie Prix de Rome, nie były obowiązkowe. Rozstrzygano je anonimowo, zwycięzcom przyznawano nagrody pieniężne, a nazwiska ich były publikowane w specjalistycznym tygodniku, „La Revue des Beaux-Arts”. Choć kobiety mogły ubiegać się o Prix de Rome dopiero od 1903 roku, były one zachęcane już wcześniej do udziału w szkolnych konkursach. Celem Juliana było bowiem przygotowanie ich do rywalizacji, jaka panowała w zawodzie artysty, wyrobienie w nich pewności siebie i podejścia, które pozwoliłoby im w przyszłości stawić czoła trudnościom i przeciwnościom artystycznego losu. Jak pisze Catherine Fehrer ${ }^{31}$, pionierka badań nad historią Akademii Julian, zaletą tej instytucji był nie tylko sam system nauczania. Była ona także miejscem spotkań i wymiany myśli w łonie społeczności studenckiej z całego świata, odznaczającej się różnorodnością i rozmaitością tradycji i bagażu kulturalnego.

${ }^{22}$ Maria Gażycz studiowała u T. Robert-Fleury'ego, A. W. Bouguereau i J. J. Lefebvre'a, w grudniu 1885 uzyskała tam wyróżnienie.

${ }^{23}$ Leona (Leonia) Bierkowska w latach 1885-1887 studiowała rysunek u Lefebvre'a i Boulangera; C. Fehrer, The Julian Academy.

${ }^{24}$ Aniela Biernacka (Poray-Biernacka), malarka (1858-1918), od 1888 roku studiowała u Julesa Lefebvre'a, Jeana-Paula Laurensa i Jeana-Josepha Benjamina-Constanta; C. Fehrer, The Julian Academy. (Wg „Catalogue général” studiowała tam w latach 1886-1892 w pracowni 27, polecona przez Annę Bilińską.)

${ }^{25}$ Dziewanowska, studiowała w pracowni B Akademii Julian w latach 1890-1892.

${ }^{26}$ Leokadia Łempicka, malarka (ur. przed 1865-1913), w 1893 wyjechała do Paryża na dalsze studia artystyczne na Akademii Julian, dzieliła wówczas pracownię z Anną Paszkiewicz, malarką i rzeźbiarką.

${ }^{27}$ Wanda Cichocka-Nałęcz, malarka (1875-?), studiowała przez cztery lata na Akademii Julian u Jeana-Josepha Benjamina-Constanta i Jeana-Paula Laurensa; C. Fehrer, The Julian Academy. $\mathrm{Wg}$ „Catalogue général” studiowała tam w 1895 roku w pracowni 27.

${ }^{28}$ Stanisława Karłowska, malarka (1876-1952), studiowała na Akademii Julian (malarstwo i rysunek) ok. 1895; C. Fehrer, The Julian Academy.

${ }_{29}$ Maria Józefa Gerson-Dąbrowska, rzeźbiarka, malarka, krytyk sztuki, pisarka (18691942), studiowała na Akademii Julian u D. Puecha, A. W. Bouguereau i G. Ferriera w latach 1896-1898; C. Fehrer, The Julian Academy. Wg „Catalogue général” studiowała tam w 1896.

${ }^{30}$ Anna Gramatyka-Ostrowska, malarka, graficzka (1882-1958), prawdopodobnie od 1900 do 1904 uczyła się w Szkole Sztuk Pięknych u Jean-Paula Laurensa. Wg C. Fehrer (The Julian Academy) studiowała u Laurensa na Akademii Julian od 1901 do 1904.

${ }^{31}$ Por.: G. P. Weisberg, The Women in the Académie Julian, [w:] Overcoming All Obstacles, s. 13-25; C. Fehrer, The Julian Academy, s. 3-4. 
Około dwudziestu Polek studiowało również na Akademii Colarossi ${ }^{32}$. Pierwszą z nich była wspomniana Maria Giżbert-Studnicka, której studia przypadły na lata 18951900. Pozostałe były to głównie artystki urodzone pod koniec lat 1870 i w latach 80 . XIX wieku Akademia Colarossi wydawała im się z pewnością instytucją bardziej awangardową, niż Akademia Julian, na którą uczęszczało poprzednie pokolenie. Na założonej w 1904 roku Académie de la Grande Chaumière, gdzie uczyła przez pewien czas Olga Boznańska, udało nam się zidentyfikować dziesięć Polek ${ }^{33}$. Były one często uczennicami Émile'a Antoina Bourdelle'a w pracowni rzeźby, a ich studia przypadły głównie na lata 1908-1913. Na pobliskiej Académie Vitti, gdzie również nauczała Boznańska odnotowano trzy polskie studentki ${ }^{34}$. Te, które przybyły do Paryża w początkach XX wieku, wybierały też studia u Maurice'a Denis na założonej w 1908 roku Akademii Ranson. Być może przyciągał je też fakt, że nauczał tam inny słynny nabista, przyjaciel Maurice’a Denis, Paul Sérusier, w swoim czasie kochanek Gabrieli Zapolskiej. Do 1918 roku na Akademii Ranson studia odbyło osiem Polek, a wśród nich Alicja Halicka ${ }^{35}$.

Ponad połowa odnotowanych przez nas artystek udała się do Paryża, by tam podjąć, bądź kontynuować studia artystyczne. Aż do drugiej połowy lat 90. XIX wieku paryskie akademie były dla polskich artystek pierwszymi zagranicznymi uczelniami, do jakich one uczęszczały. Później przyjeżdżały już one często do Paryża nie tylko po studiach w Polsce, ale także w szkołach Monachium lub Wiednia. Oprócz lub zamiast studiów w prywatnych akademiach niektóre z nich wybierały École des Beaux-Arts (od kiedy było to możliwe) lub bardziej tradycyjny sposób kształcenia w pracowniach mistrzów, w tym również u osiedlonych w Paryżu Polaków, np. u Olgi Boznańskiej, jak

\footnotetext{
${ }^{32}$ Były wśród nich: Zofia Albinowska-Minkiewiczowa, malarka (1886-1971), Nina Alexandrowicz, malarka, rzeźbiarka (1877-1945), Jadwiga Gałęzowska (Malinowska-Gałęzowska), Maria Giżbert-Studnicka, Helena (Chaja) Głogowska, rzeźbiarka (1893-1972), Anna Harland Zajączkowska, malarka (1883-1930), Zofia Katarzyńska-Pruszkowska, malarka (1887-1957), Wacława Kiślańska, Wanda Komorowska, graficzka, malarka (1873-1946), Felicja Kossowska, malarka (1886-1956), Stefania Kossowska-Daniel, malarka (1872-1952), Maria Koźniewska-Kalinowska, malarka (1875-1968), Ewa Lorentowicz z Rościszewskich, malarka (1873-1944), Helena Lustgarten-Ogrodzka; Irena Łuczyńska-Szymanowska, malarka (1890-1966) czy Maria Niedzielska, malarka (1876-1947), Leokadia Maria Ostrowska (Łodzia de Ostrowska, Łodzia-Ostrowska), malarka (1875 lub 1879-1952), Aniela Pająkówna. Mówi się również o krótkiej tam nauce Meli Muter (1876-1967). W przypadku polskich studentek na Akademii Colarossi musimy zaufać podawanym przez nie same lub ich biografów informacjom, nie mogąc oprzeć się na źródłach archiwalnych, pochodzących z samej Akademii. Na krótko przed zamknięciem Akademii w 1930 roku małżonka jej właściciela spaliła bowiem archiwa szkoły, by zemścić się w ten sposób za zdrady męża.

33 Zofia Billauer-Węgierkowa, malarka, scenografka (1893-po 1975); Janina Broniewska; Helena (Chaja) Głogowska, Karolina Grabowska, malarka, rzeźbiarka (1861-1920), Wanda Kossecka, Helena Lustgarten-Ogrodzka, Mela (Maria, Melania) Muter (Mutermilch), Kazimiera Pajzderska-Małaczyńska z Hellerów, rzeźbiarka, malarka (1879-1959), Emilia Bibianna Parczewska, malarka (1877-1962), Maria Schayer (Górska-Schayer), malarka (1878-1944).

${ }^{34}$ Maria Koźniewska-Kalinowska, Eleonora Onimichowska z Kotwicz-Spleszyńskich, malarka (1869-1962), Maria Zaręba.

${ }^{35}$ Oprócz Halickiej uczęszczały tam: Zofia Baudouin de Courtenay, malarka (1887-1967) w latach 1908-1909; Zofia Bojczuk z Nalepińskich, malarka, graficzka (1885-1938?) również w latach 1908-1909, obie należące do grupy Bizantynistów, Felicja Kossowska w 1911/1912, Michalina Krzyżanowska, malarka (1883-1962) w 1907, Stefania Łazarska z Krautlerów, malarka (1886 lub 1887-1977), Zofia Trzcińska-Kamińska, rzeźbiarka (1890-po 1972) w latach 1911-1912.
} 
to miało miejsce w przypadku Stanisławy Marii Kraszewskiej ${ }^{36}$, Marii Koźniewskiej-Kalinowskiej ${ }^{37}$, Eleonory Plutyńskiej czy Emilii Parczewskiej. Jak wskazują przytoczone powyżej dane, Polki nierzadko studiowały kolejno w kilku akademiach, szukając bądź to najkorzystniejszych warunków, bądź najodpowiedniejszych profesorów, metod nauczania czy nauczanych trendów.

Polki zaczęły przyjeżdżać do Paryża w latach 80. XIX wieku W pierwszym dziesięcioleciu przybyło ich tam ok. dwunastu, a w latach 90. ok. osiemnastu. Najwięcej jednak, bo ok. pięćdziesięciu, pojawiło się nad Sekwaną w pierwszym dziesięcioleciu XX wieku. Tendencja ta utrzymywała się również w latach 1910-1918. Ponad jedna czwarta z nich, czyli około czterdziestu (wyłączywszy z naszych obliczeń te artystki, które znamy jedynie z nazwiska) osiedliła się tam bądź na stałe, bądź spędziła tam dużą część swego aktywnego życia zawodowego. Należą do nich, obok Olgi Boznańskiej i Meli Muter, którym poświęcimy nieco więcej miejsca, Anna Bilińska, Alicja Halicka, Sara Lipska, Nina Alexandrowicz, Ela Dziubaniuk, Tola Certowicz, Karolina Grabowska, Zofia Grużewska, Stanisława Kraszewska-Strzemboszowa, Stefania Łazarska, Aniela Pająkówna, Maria Rubczak (wystawiająca pod męskim pseudonimem Guy Bertin), Zofia Święcka-Martin, Zofia Piramowicz czy Helena Kwiatkowska.

Wspomniany wyżej Wacław Gąsiorowski pisał w ten sposób o sytuacji polskich artystek w Paryżu:

kobiety artystki niemal wszystkie i nawet te, które zdobyły sobie rozgłos, posiadają bądź własne kapitaliki i dochody, nie mające nic ze sztuką wspólnego, bądź zaopatrzenie domowe. Nędza pośród nich bywa wyjątkowym zjawiskiem. Ma to swoje bezpośrednie następstwo w sumie pracy. Ilość dzieł artystek Polek na wystawach paryskich jest stosunkowo trzy razy większa, niż artystów Polaków ${ }^{38}$.

Idąc śladem Gąsiorowskiego, zanalizowałam ${ }^{39}$ nie liczbę wystawianych prac, a liczbę wystawiających, co pozwoliło mi na wyciągnięcie wielu wniosków. W 1884, roku założenia Salonu Niezależnych, wystawiało na nim dwóch Polaków. Udział ten wzrastał stopniowo, by osiągnąć liczbę pięćdziesięciu jeden osób w 1913 roku. Kobiety Polki w osobie panny Elli Rubis, uczestniczyły po raz pierwszy w Salonie Niezależnych w 1888 roku, stanowiąc 33 procent wystawiających Polaków. Proporcja ta regularnie wzrastała. Gwałtowny skok nastąpił w 1910 roku, kiedy to liczba uczestniczących w Salonie Polaków wzrosła z trzynastu do trzydziestu czterech (czyli nieco mniej niż trzykrotnie), w tym kobiet z czterech do piętnastu (niemal czterokrotnie). W 1910 roku kobiety stanowiły 44 procent wystawiających Polaków. Przed samą wojną, w 1914 roku kobiety stanowiły ok. 41 procent wystawiających.

Proporcje te przedstawiały się nieco inaczej w przypadku Salonu Jesiennego. W roku jego założenia, 1903, wystawiło na nim swoje prace sześciu polskich artystów. Liczba ich zwiększała się rokrocznie i w 1907 roku doszła do czternaściorga, w tym dwie kobiety (czyli niecałe 15 procent). W 1913 roku było czterdziestu ośmiu Polaków, w tym piętnaście kobiet, co stanowiło ok. 31 procent. O ile więc liczba wszystkich

${ }^{36}$ Por. jej obraz Boznańska malująca portret pianisty Radwana, 1903, Biblioteka Polska w Paryżu, a także Boznańskiej Portret Stanistawy Kraszewskiej-Strzemboszowej, 1905, Muzeum Narodowe w Poznaniu.

${ }^{37}$ Boznańska namalowała Portret Marii Koźniewskiej-Kalinowskiej ok. 1903, Muzeum Narodowe w Warszawie, w depozycie w Muzeum Okręgowym w Toruniu.

${ }^{38}$ W. Gąsiorowski, Emigracja intelektualna.

${ }^{39} \mathrm{~W}$ oparciu o listy artystów opublikowane w: H. Bartnicka-Górska i J. Szczepińska-Tramer, W poszukiwaniu światła, ksztattu i barw. 
Polaków wystawiających na Salonie Jesiennym i na Salonie Niezależnych była porównywalna (odpowiednio 48 i 51), o tyle liczba uczestniczących w nich kobiet miała się jak 5:7. Różnica ta tłumaczy się, być może, tym, że udział w Salonie Jesiennym był uwarunkowany decyzją jury, prawdopodobnie mniej sprzyjającego kobietom.

Kolejnym interesującym kryterium osiągnięć artystycznych są zakupy dzieł, dokonane przez rząd francuski ${ }^{40}$ do kolekcji państwowych. Wśród zakupionych $\mathrm{w}$ ten sposób prac Polek znalazły się dwie prace Niny Aleksandrowicz ${ }^{41}$, jedna praca Jadwigi Bohdanowicz-Konczewskiej ${ }^{42}$, jeden obraz Ireny Reno (wł. Hassenberg) ${ }^{43}$; dwie prace Wandy Chełmońskiej ${ }^{44}$; dzieła Alicji Halickiej ${ }^{45}$; nieznane nam dziś prace którejś z panien Kwiatkowskich w latach 1908, 1925 i 1928; dzieła Sonii Lewickiej w 1911, w 1926, w 1928 (Droga z Orange) i w 1938 (pośmiertnie). Prace Blanki Mercère, których nie udało się zlokalizować, miały jakoby zostać zakupione w 1910 roku. Trzy zakupione przez państwo francuskie obrazy Olgi Boznańskiej są dziś w zbiorach paryskiego Muzeum Orsay ${ }^{46}$. Około dziesięć prac Meli Muter jest rozparcelowanych w Muzeum Sztuk Pięknych w Lyonie, Nantes, w Musée Goya w Castres, w Muzeum Sztuki i Historii w Belfort, Muzeum Pont-Aven, w Muzeum Narodowym Sztuki Nowoczesnej w Paryżu i w Muzeum Sztuki Nowoczesnej Miasta Paryża. W tym samym interesującym nas okresie rząd francuski zakupił prace ok. trzydziestu artystów polskich mężczyzn (czyli trzy razy więcej niż kobiet). Jeśli jednak wziąć pod uwagę, że kobiety stanowiły jedną czwartą polskiej kolonii artystycznej we Francji, proporcja ta jest dowodem sukcesu polskich artystek.

Portret panny Dygat Olgi Boznańskiej jest jednym z pierwszych zakupów dzieł Polaków przez rząd francuski. Kariera malarki służyć może jako znakomite studium przypadku polskich „emancypantek” w Paryżu. Boznańska reprezentuje grupę polskich artystek, które przybyły do stolicy Francji już jako dojrzałe twórczynie. Okres jej artystycznej edukacji, odbytej w Krakowie m.in. na wspomnianych Kursach Baranieckiego i w prywatnych szkołach monachijskich, należał już dawno do przeszłości. W 1898 roku, w chwili osiedlenia się w Paryżu miała ona 33 lata i duże sukcesy, odniesione m.in. w Monachium i w Paryżu, liczne wystawy, m.in. w Warszawie, Berlinie, Dreźnie, Pradze, Wiedniu, Londynie, Lwowie, a prace jej zdobywały medale i były przedmiotem zakupów muzealnych. Jednak to udział w paryskim Salonie w 1896 miał dla niej znaczenie symboliczne: był konsekracją kariery i potwierdzał słuszność wyboru jej drogi życiowej. Świadczy o tym jej często cytowany, entuzjastyczny list do ojca z 18 kwietnia $1896^{47}$ o przyjęciu jej dwóch prac na Salon. Dwa lata później Boznańska osiadła w Paryżu, by zostać wielką, uznaną artystką. Wydaje się, że to właśnie ta ambicja kazała jej odrzucić zaszczytną propozycję Juliana Fałata objęcia kierownictwa

\footnotetext{
${ }^{40}$ Dokumenty dotyczące zakupów państwowych zachowane we francuskich archiwach narodowych nie zawsze są spójne i kompletne, stąd konieczność ich bardzo ostrożnej interpretacji.

${ }^{41}$ Kwiaty (zakupione w 1928 roku, obecnie w Muzeum w Cahors), oraz Kwiaty (zakupione w 1937 roku, obecnie w Muzeum w La Rochelle).

42 Jawajka, zakupiona w 1928 roku, obecnie w Muzeum w Cambrai.

${ }^{43}$ Aktualnie w Musée Château w Dieppe.

${ }^{44}$ Zakupiony w 1927 roku gwasz Procesja jest aktualnie w zbiorach Musée d'Orsay.

${ }^{45}$ Martwa natura ze skrzypcami, 1918 (dziś w Muzeum Sztuk Pięknych w Bordeaux); Martwa natura, przed 1925, zakupiona w 1926 oraz Place de la Concorde, 1933, zakupiony w 1938 (oba dzieła dziś w Muzeum Narodowym Sztuki Nowoczesnej w Paryżu).

${ }^{46}$ Portret panny Dygat, zakupiony w 1904; Portret młodej kobiety, zwany też Portretem młodej kobiety w bieli, zakupiony w 1912; Portret pani D., zakupiony w 1913.

${ }^{47}$ H. Blum, Olga Boznańska. Zarys życia i twórczości, Kraków 1964, s. 37-38.
} 
katedry malarstwa dla kobiet w Szkole Sztuk Pięknych w Krakowie. Nie miejsce tu na wspominanie całej historii w szczegółach ${ }^{48}$. Artystka miała różne powody, by nie przyjąć tej propozycji. Jednym z nich była uraza do mieszkańców swego rodzinnego miasta z powodu odrzucenia jej obrazu z jednej z oficjalnych wystaw ${ }^{49}$. Jednak słowa:

Gdybym musiała z obowiązku być w Krakowie, byłoby mi smutno pewnie, ale myśl, że obowiązek mnie tam trzyma, byłaby nagrodą, ale ja nie czuję i nie uczułam się zobowiązana poświęcać swego malarstwa i siebie samej dla kilku głupich nadętych panien, które $\mathrm{z}$ braku innego zajęcia brałyby się na kilka miesięcy do sztuki. Na to jest mi mój zawód zanadto ważny ${ }^{50}$

— należy z pewnością interpretować jako ambicję osiągnięć, dla których pobyt w Paryżu był warunkiem koniecznym. Dowodem na to, że to nie sama praca pedagoga ją zniechęcała, było przyjęcie roli profesora na Akademii Vitti ${ }^{51}$ w Paryżu w 1908 roku, gdzie wśród studentów byli Polacy. Rok później wśród siedmiu jej uczennic — Amerykanek, Angielek i jednej Litwinki zaakceptowała dwie Polki ${ }^{52}$. Należy wierzyć, że nie były to „głupie, nadęte panny”, jakie obawiała się spotkać w pracowni kobiecej krakowskiej

${ }^{48}$ W 1896 roku złożona została petycja uczennic kursów Baranieckiego do władz galicyjskich o przyznanie im prawa kształcenia się w krakowskiej szkole sztuk pięknych. Jakkolwiek dyrekcja szkoły przyznała, że: „Stan umysłowy wykształcenia w ogóle kobiet zwłaszcza w kraju naszym w obecnym czasie tak się bardzo korzystnie rozwinął i takie niespodziewane $\mathrm{z}$ niego powstały następstwa, iż w każdym kierunku polskie kobiety mają już teraz wybitne u nas znaczenie. Nie tylko w literaturze krajowej, lecz nadto w dziedzinie sztuk pięknych wykazują one szereg przedstawicielek mających ustalony już rozgłos; dość wspomnieć nazwiska panien Certowiczówny, Bierkowskiej, Dulembianki, Rożniatowskiej, Milewskiej, Pająkówny itp. - nie mówiąc już o Bilińskiej, Boznańskiej, których prace na zagranicznych wystawach są bardzo cenione, a nawet poszukiwane. Ta dążność w kraju naszym kobiet do prac umysłowych i wybitne ich stanowiska tym bardziej godne są i podziwiane, i pochwalmy, że one wyłącznie tylko mocą mrówczej pracy charakteru swego i wytrwałością niezwykłą na takie pochlebne stanowiska wybić się zdołały, nie tylko nie mając żadnej za sobą opieki, ani rządowej, ani społecznej, lecz nadto spotykając wszędzie albo zawady, albo nawet niezwyciężone trudności”; cyt. za: Materiały do dziejów Akademii Sztuk Pięknych w Krakowie, s. 207-208. Dyrekcja uczelni uzależniła jednak możliwość kształcenia kobiet od powiększenia gmachu szkolnego oraz liczby profesorów, bowiem ,nauki i wykłady dla nich odbywałyby się w odosobnieniu, w sali przeznaczonej dla nich osobno”. Jak donosiła z kolei prasa wiedeńska: „W myśl nowej organizacji zakład ten [Szkoła Sztuk Pięknych - E.B.] uzyska na przyszłość prawo przyjmowania kobiet. Obecnie dziewczęta, które mają zamiłowanie i talent do malarstwa i rysunków kształcą się na tutejszych wyższych kursach Baranieckiego. Wysłały one niedawno do Koła Polskiego i Ministerstwa Oświaty petycję, aby wolno im było kształcić się w szkole malarstwa lub Akademii. Jak donoszą obecnie z Krakowa, pragnieniu temu stanie się zadość, a kierowniczką oddziału żeńskiego Akademii malarstwa zostanie rodowita krakowianka, polska malarka Olga Boznańska..."; Neue Freie Presse (Wiedeń) 6.04.1896, cyt. za: H. Blum, Olga Boznańska. Zarys życia, s. 130.

${ }^{49}$ Por.: tamże, s. 41.

${ }^{50}$ Tamże, s. 42.

${ }^{51}$ Por.: List Olgi Boznańskiej do Julii Gradomskiej, Paryż, 1908, w: H. Blum, Olga Boznańska, Warszawa 1974, s. 70.

${ }^{52}$ W dniu 24 stycznia 1909 pisała w ten sposób do Ludwika Pugeta: „Chciał Sz. Drogi Pan mieć wiadomości po pierwszej lekcji mojej. Otóż są tylko trzy uczennice, czwarta umarła, Angielka [...]"; H. Blum, Olga Boznańska, s. 70. Pod koniec roku sytuacja była inna, w dniu 20 grudnia donosiła bowiem Julii Gradomskiej: ,[...] wiesz, że jestem profesorem w akademii prywatnej od mojego powrotu. Mam siedem uczennic, dwie Polki, panna Kurnatowska, której ojciec jest bogatym obywatelem w kaliskiej guberni i zarządcą dóbr na Podolu w okolicy Żytomierza. Druga jest Litwinka z Wilna. Reszta Angielki i Amerykanki”; tamże, s. 72. 
uczelni. Wyżej cytowane zdanie świadczy również o opinii, jaką artystka miała na temat Krakowa jako ośrodka artystycznego i jego mieszkanek jako artystek, które nie mogły zajmować się sztuką inaczej, jak tylko z braku lepszego zajęcia, amatorsko, na kilka miesięcy. Zastrzeżeń tych nie miała wobec studentek uczących się w Paryżu. Sama była najlepszym przykładem, że Kraków mógł wydać przecież twórców wielkiej klasy.

Jej paryska strategia sukcesu polegała na częstym i regularnym wystawianiu oraz zdobywaniu i gruntowaniu sławy portrecistki. W 1898 zorganizowała wystawę indywidualną w galerii Georgesa Thomasa (wspólnie ze swoim kuzynem, zajmującym się grafiką reprodukcyjną, Danielem Mordantem, który zapewne ułatwił akceptację młodej artystki w tej znanej paryskiej galerii, aczkolwiek i Ślewiński miał tam wystawy w 1897 i 1898). Jej wystawy w galeriach należały jednak do wyjątków. Najczęściej brała udział w salonach. Salonowi Société nationale des beaux-arts pozostała wierna przez ponad trzydzieści lat. To dzięki uczestnictwu w salonach rząd francuski dokonał zakupów jej dzieł. Udział w Wystawie Światowej w Paryżu w 1900 roku przyniósł jej wyróżnienie. Choć wystawiała zarówno kwiaty, jak i martwe natury, to jednak nacisk kładła na portrety. Początkowo prezentowała portrety modeli nieznanych szerszej publiczności. Ich nazwiska często zastępowały inicjały. Portretowała zarówno Polaków, jak i przedstawicieli innych narodowości, w tym ważne osobistości z francuskiego świata sztuki, jak wspomnianego wyżej Georgesa Thomasa (1899); krytyka Henri-Pierre'a Roché (1906); marszanda i kolekcjonera Louisa Libaude'a (1907), poetę i krytyka Pierre'a Tourniera (ok. 1912), poetę, dramaturga i krytyka teatralnego, bibliofila i amatora Edouarda Franchettiego (ok. 1912); krytyka sztuki, autora licznych książek, m.in. na temat Mary Cassatt, Achille'a Segarda (ok. 1910). Dopiero jednak w 1911 roku zdecydowała się pokazać na salonie portrety znanych osobistości, używając w tytule ich pełnego nazwiska. Byli to poeci: zapomniana dziś Edmée Delebecque oraz Belg piszący po francusku, Emile Verhaeren. Rok później Boznańska wystawiła portret francuskiej pisarki Gabrielle Reval ${ }^{53}$. W 1913 roku wreszcie zaprezentowała portret cenionego we Francji autora Quo Vadis?, laureata Nagrody Nobla, Henryka Sienkiewi$\mathrm{cza}^{54}$. Znane nazwiska portretowanych przyciągnęły uwagę krytyków, którzy mówili o artystce coraz lepiej i coraz więcej. Zaczęły pojawiać się artykuły monograficzne ${ }^{55}$.

Obok salonów, malarka uczestniczyła w wystawach grupowych organizowanych w galeriach, np. z grupą Intymistów i Syntetystów w Galerii Devambez w 1909, 1910 i w 1913. Wystawiała tam w międzynarodowym, mieszanym towarzystwie m.in. Isabel Beaubois, Hélène Dufau, Jane Poupelet, Henri Caro-Delvaille'a, braci Schnegg, Raymonda Wooga, Gastona La Touche, Beatrice How, Ernesta Laurenta, Dufresne'a, Lemordanta, Signaca czy Klingsora oraz właściciela galerii, francuskiego malarza, autora scen religijnych i portretów, André Devambeza.

Artystka nie stroniła także od wystaw w towarzystwie kobiet. Być może zachęcił ją do tego złoty medal zdobyty na Wystawie Kobiet Malarek w Londynie w 1900 roku. W latach 1909 (w Galerie des Artistes Modernes), 19105, 1913 (w galerii Roger Levesque) i 1919 uczestniczyła w wystawach małej, międzynarodowej grupy Les Quelques (Kilka), skupiającej malarki i rzeźbiarki. Wystawy te nie wzbudzały entuzjazmu kryty-

${ }^{53}$ Wystawiony w ramach wystawy zakupów państwowych Les achats de l’Etat, Szkoła Sztuk Pięknych, Paryż, 1912, obecnie w Muzeum Narodowym w Krakowie.

${ }^{54}$ Wystawiony pod nr 158, Salon de la société nationale des beaux-arts, Paryż, 1913.

${ }^{55}$ Por.: M. Goth, Olga de Boznańska, Gil Blas (Paryż) 10.09.1913; tenże, Olga de Boznańska, L'Art et les Artistes 1913 nr 105, s. 129-134.

${ }^{56}$ W 1910 roku w Galerie des Artistes Modernes odbyła się czwarta, a druga z udziałem Boznańskiej, wystawa „Quelques”, w towarzystwie około trzydziestu innych artystek, w tym Meli Muter. 
ki, choć prace samej Boznańskiej były dobrze oceniane ${ }^{57}$. Artystka wzięła udział również w ekspozycjach, organizowanych przez dwa inne stowarzyszenia kobiece. W 1912 pokazała ona swe prace w galerii Roger Levesque w Paryżu wraz z założonym sześć lat wcześniej amerykańskim stowarzyszeniem International Art Union. Na wystawie tej za obraz Macierzyństwo $^{58}$ zdobyła nagrodę Whitney Hoff Museum, ufundowaną przez Grace Whitney Hoff, znaną filantropkę i kolekcjonerkę. W 1913 roku artystka uczestniczyła w wystawie Unes Internationales w paryskiej Galerie Reitlinger. Na początku lat 30. XX wieku Boznańska związała się z innym kobiecym stowarzyszeniem artystycznym Femmes artistes modernes, założonym w 1931 roku $^{59}$, z którym wystawiała przez cały okres jego istnienia, czyli do 1938 roku $^{60}$.

Również jej quasi-indywidualne ekspozycje odbywały się w gronie kobiecym. W 1909 roku była główną bohaterką kobiecej wystawy „Cent tableaux. L'Exposition des «Mademoiselle». L'oeuvre d'Olga de Boznańska. Deux tableaux de C.-H.Dufau. Deux pastels de Geneviève Granger" ${ }^{\prime 61}$ w Petit Musée Beaudouin, obszernej galerii, usytuowanej przy eleganckiej, handlowej ulicy Saint-Honoré, w samym sercu burżuazyjnego, prawobrzeżnego Paryża. Boznańska pokazała tam około trzydziestu dzieł. Pochlebny dla artystki wstęp do niewielkiego katalogu sygnowany był przez zaprzyjaźnionego z nią kustosza Muzeum Luksemburskiego w Paryżu, Leonce'a Bénédite'a ${ }^{62}$. Louis Vauxcelles, znany paryski krytyk, choć nie popierał samego kontekstu wystawy, zorganizowanej w lokalu wziętego jubilera, chwalił śmiałość wyboru Boznańskiej jako artystki wiodącej $^{63}$. Uważał bowiem, że dzieła jej, ,podobizny niepokojące i tajemnicze, pełne intensywnego życia wewnętrznego", wprawiały w zakłopotanie burżuazyjną publiczność:

Panna Boznańska nie robi portretu sukni, kapelusza, etoli, czy kolii brylantowej [...]

Stara się ona oddać uczucia, melancholijne lub czułe uśmiechy, głęboki smutek, żywe lub bolesne emocje, a także charaktery ${ }^{64}$.

Edouard Sarradin pisał zaś o niej w ten sposób:

${ }^{57}$ J.-L. Vaudoyer, Petites expositions - International Art Union, La Chronique des arts et de la curiosité 23.01.1909, s. 280; tenże, Petites expositions. Les Quelques, La Chronique des arts et de la curiosité 15.05.1909.

${ }^{58}$ Autor i tytuł nieznani, wycinek z paryskiej gazety Gil Blas (19.09.1912), Biblioteka Czartoryskich Muzeum Narodowe w Krakowie, rkp. nr 1068.

${ }^{59}$ Więcej na temat tego stowarzyszenia, w którym wystawiały również inne polskie artystki: Mela Muter, Alicja Halicka, Nina Aleksandrowicz i Tamara de Łempicka zob.: P. Birnbaum, Women Artists in Interwar France, Farnham-Burligton 2011.

${ }^{60}$ Por. katalogi wystaw: Les Femmes artistes modernes. Exposition de peintures-sculptures arts décoratifs, du 12 février au 1 mars 1932, Théâtre Pigalle, 12 rue Pigalle, Paris 1932; Les Femmes artistes modernes. Exposition de peintures-sculptures arts décoratifs, du 24 mai au 10 juin 1934, La Maison de France, 101 avenue des Champs-Elysées, Paris 1934; Les Femmes artistes modernes. Exposition de peintures-sculptures arts décoratifs, du 28 mai au 7 juin 1935, Galerie Bernheim-Jeune, Paris 1935; Les Femmes artistes modernes. Exposition de peintures-sculptures, du 20.08 au 4 septembre 1937, Pavillon des expositions, Esplanade des Invalides, Paris 1937.

${ }^{61}$ Cent tableaux. L'Exposition des „Mademoiselle”. L'oeuvre d'Olga de Boznańska. Deux tableaux de C.-H.Dufau. Deux pastels de Geneviève Granger, [katalog wystawy], Paris 1909, przedmowa: Léonce Bénédite.

${ }^{62}$ Tamże.

${ }^{63}$ L. Vauxcelles, Le Petit Musée Beaudouin, Gil Blas (Paryż) 29.08.1909.

${ }^{64}$ Bibliothèque littéraire Jacques-Doucet w Paryżu, Fonds Vauxcelles 166, L. Vauxcelles, Peinture féminine, [tytuł czasopisma nieznany] 12.12.1909, wycinek prasowy; por.: J. F. Schnerb, Exposition des „Mademoiselle”, La Chronique des arts et de la curiosité 12.12.1909. 
Najrozmaitsze i najbardziej zniuansowane szarości zlewały się w jakąś melodię tak pełną słodyczy i doskonałości, że można by ją odnaleźć tylko u Whistlera. Ale to wcale nie był Whistler, tak jak portret pędzla Berthe Morisot nie jest portretem namalowanym przez Moneta ${ }^{65}$.

W kobiecy kontekst wpisywała się także kolejna wystawa quasi-indywidualna ${ }^{66}$ artystki, którą zorganizowała ona w roku 1912 w Lyceum Club w Paryżu wraz z francuską rzeźbiarką Jane Poupelet ${ }^{67}$.

Boznańska nie należała jednak do wojujących feministek. Nie udało się dotychczas natrafić na ślady jej żywszych kontaktów np. ze znaną w Paryżu polską pisarką, dziennikarką i malarką, zaangażowaną w ruch feministyczny we Francji, Marią Szeligą (1854-1927), choć obie panie zetknęły się ze sobą wielokrotnie w polskim środowisku intelektualnym Paryża ${ }^{68}$. Szeliga (wł. Maria Mirecka), działaczka patriotyczna, a także członkini Gminy Narodowo-Socjalistycznej, założycielka Union Universelle des Femmes, publikująca w czasopiśmie „La Revue Féministe”, uczestniczka kongresów, przybyła do Paryża w 1878 roku. W 1897 roku założyła Théâtre Féministe, który stanowić miał platformę wypowiedzi dla autorek dramatycznych. Na jego deskach wystawiła swoja sztukę L'Ornière (Koleina), akcentującą kwestie emancypacyjne kobiet. W 1908 roku założyła polską sekcję stowarzyszenia Salon International, do której należały także Maria Gierszyńska, Melania Rajchman (publikująca we Francji pod pseudonimem J. Orka), hrabina Skarbek oraz przyjaciółka i uczennica Boznańskiej, Stanisława Maria Kraszewska.

Boznańska nie brała także udziału w wystawach o charakterze kobiecym poza Francją, nie licząc kilku wystaw w Londynie ${ }^{69}$ oraz zorganizowanej w 1917 roku we Lwowie I Wystawy Sztuki Artystek Polskich, aczkolwiek wystaw za granicą, w Europie i w Stanach Zjednoczonych, nie zaniedbywała. Nie zabiegała również o to, by znaleźć się na łamach prasy feministycznej, która zauważyła ją stosunkowo późno i początkowo pisała o niej zresztą niezbyt pochlebnie ${ }^{70}$. Prasa ta jednak skwapliwie skorzystała $\mathrm{z}$ rosnącej sławy polskiej artystki, żeby rewindykować prawo kobiet do posiadania artystycznego geniuszu ${ }^{71}$. Wystawy kobiece były dla Boznańskiej kolejną okazją do pokazania swoich prac. Organizowane przez grupy lub stowarzyszenia, wymagały one od niej niewątpliwie mniej wysiłku, niż wystawy indywidualne. Jednak na pytanie, czy w efekcie były one najlepszą z możliwych artystycznych strategii, należałoby odpowiedzieć przecząco. Mające często jeśli nie złą, to w każdym razie umiarkowaną prasę, nie przynosiły takich efektów, jak zakupy państwowe i pochlebne krytyki, jakie dawał udział w salonach.

${ }^{65}$ E. Sarradin, Les portraits de Mlle Olga de Boznanska, Le Journal des Débats 26.12.1909.

${ }^{66}$ M. Elder, Des expositions, La Vie $1912 \mathrm{nr} 6$.

67 „Exposition de peinture et de sculpture”, Lyceum Club, Paris 1912.

${ }^{68}$ W jedynym liście Marii Szeligi do Olgi Boznańskiej z 18 września 1903, Szeliga wyraża nadzieję osobistego poznania malarki; Muzeum Narodowe w Krakowie, Biblioteka Książąt Czartoryskich, sygn. 1063, korespondencja Olgi Boznańskiej.

${ }^{69}$ Women Exhibition, Earl Court, New Gallery, Londyn 1900 (artystka zdobyła tam złoty medal); Eleventh Annual Exhibition, Women's International Art Club, Grafton Gallery, Londyn 1910.

${ }^{70}$ C. Misme, Les Oeuvres de femmes au Salon de la Société nationale des beaux-arts, La Française $1910 \mathrm{nr} 159$.

${ }^{71}$ Taż, Les Oeuvres de femmes au Salon de la Société ntionale des beaux-arts, La Française 1912 nr 240, Taż, Les Oeuvres de femmes au Salon de la Société nationale, La Française $1913 \mathrm{nr}$ 277. 
Powszechnie uważa się, że Boznańska poświęciła osobiste szczęście dla sztuki. Kwestia poświęcenia szczęścia osobistego dla kariery zawodowej, tak sprzecznej z ówczesnymi poglądami na rolę kobiety, według których nie powinna ona była osiągać mistrzostwa w żadnej dziedzinie, jest w przypadku Boznańskiej delikatna. Często wspomina się o długoletnim narzeczeństwie z malarzem Józefem Czajkowskim, brutalnie przez niego zerwanym. Równie często zapomina się o kilku kolejnych przyjaźniach z mężczyznami, które zapewne należały do kategorii amitiés amoureuses, a wśród nich z Franciszkiem Mączyńskim, Bohdanem Faleńskim, Wiktorem Backiem czy Włodzimierzem Światłowskim. Choć obiegowe opinie starają się zamknąć Boznańską w czterech ścianach jej pracowni, to jednak zachowana korespondencja i dzieła świadczą o jej ożywionym życiu towarzyskim i licznych podróżach. Życie artystki było całkowicie zdominowane przez jej pracę zawodową, ale widzieć w tym fakcie należy jej konsekwentny, wolny wybór, podyktowany ambicją i pragnieniem osiągnięcia sukcesu. Z czasem ambicja ta zamieniła się w całkowitą samorealizację w pracy. Stało się to jednak dopiero po pierwszej wojnie światowej, kiedy z wiekiem artystka ostatecznie poniechała zamiaru założenia rodziny, zaś zupełnie odmieniona rzeczywistość „,szalonych lat” sprzyjała sukcesom młodszych pokoleń i ich nowej, spektakularnej, agresywnej i agresywnie propagowanej sztuce. Czy wynikającą stąd samotność zdołały wypełnić seanse pozowania modeli, czy malowane od czasu do czasu sceny macierzyństwa, tego nie wiemy.

Podsumowując artystyczne osiągnięcia malarki powiedzieć należy, że być może nie osiągnęła ona sukcesów na miarę swego talentu. Nie stała się prawdziwą gwiazdą rodzącego się ,star systemu”, jak to było np. w przypadku Tamary Łempickiej. Z dzisiejszego punktu widzenia nie jesteśmy w stanie dokładnie określić, jaka była właściwie jej pozycja w ówczesnym artystycznym świecie. Jak wiadomo, już wówczas korespondenci rodzimej prasy mieli tendencje do wyolbrzymiania sukcesów polskich artystów zagranicą, w tym również w Paryżu, uprawiając rodzaj ,propagandy sukcesu” ku „pokrzepieniu serc”. Równocześnie jednak dopiero dziś odkrywamy, że krytycy w prasie amerykańskiej ${ }^{72}$ mówią o niej regularnie i w superlatywach w sprawozdaniach z wystaw i salonów. Charakter samej artystki, skromnej, ambitnej i z pewnością również dumnej, nie pozwalał jej zabiegać o sławę. Czy znaczenie miała także jej płeć? Sto lat temu samotna kobieta, wychowana w cieplarnianych warunkach, nie była praktycznie przygotowana do stawienia czoła trudnościom życiowym. A jednak fakt bycia kobietą nie przeszkodził jej w osiągnięciu pozycji wziętej portrecistki, uczestniczeniu w bardzo licznych wystawach zarówno lokalnych, jak i międzynarodowych, zdobywaniu medali i wyróżnień, członkostwie w prestiżowych stowarzyszeniach artystycznych, zakupach państwowych, przyciągnięciu uwagi krytyki, czy wreszcie prowadzeniu pracy pedagogicznej. Paryż i jego sprzyjająca artystom atmosfera i dobra organizacja warunków artystycznego działania jej to na pewno ułatwiły i uczyniły z niej nie zagorzałą feministkę, ale modelową emancypantkę.

${ }^{72}$ Por. m.in.: International Exhibition at Pittsburgh, American Art News 7.05.1910; Paris Letter, American Art News 1910 nr 31, s. 5; Paris Letter, American Art News 1911 nr 26, s. 5; Annual Exhibition Carnegie Institute, Fine Arts Journal 1914 nr 6, s. 288-295; The New Salon, American Art News 1914 nr 29, s. 2, 5; D. Defries, Olga de Boznańska, The American Magazine of Art Art and Progress 1917 t. 10; Pittsburgh, American Art News 1918 nr 32, s. 3; M. C., Paris Letter, American Art News 1920 nr 31, s. 3; Sales at Pittsburgh, American Art News 1920 nr 30, s. 6; Sales at Pittsburgh, American Art News 1920 nr 34, s. 5; M. C., Paris Enjoys Great Polish Art Display, American Art News 1921 nr 33, s. 7; Art in Belgium, American Art News 1921 nr 14, s. 3; M. C., Paris, American Art News 1922 nr 31, s. 1-10; H. S. C., Salon des Tuileries Proves a Success, The Art News 1923 nr 34, s. 1, 6; H. S. C., Paris, The Art News 1924 nr 40, s. 7. 
Młodsza o dwanaście lat od Boznańskiej, urodzona w 1876 roku Mela Muter, udała się do Paryża w 1901, a wiec zaledwie trzy lata później. W przeciwieństwie do swojej starszej koleżanki, była nie tylko mężatką, ale również matką. Nie miała też za sobą studiów. W Paryżu uczęszczała krótko na Akademię Colarossi, i być może także na Akademię Grande Chaumière (ta jednak powstała dopiero w 1904 roku). Sama artystka uważała się za artystycznego samouka.

Muter zdaje się być dokładnym przeciwieństwem Boznańskiej pod każdym względem, i osobistym, i artystycznym. Charakter twórczości obu malarek był porównywany już za ich życia ${ }^{73}$. Tak widział ich artystyczne przeciwieństwo młody francuski krytyk Max Goth, admirator talentu Boznańskiej, później związany z Francisem Picabią i ruchem Dada:

Tu obok Olgi de Boznańskiej mam ochotę umieścić Mutermilch, o wizerunkach mniej delikatnie ekspresyjnych, mniej refleksyjnie pieszczotliwych, ale o finezji psychologicznej równie mocnej i bardziej bezpośredniej. Boznańska opowiada drżącym głosem, Muter wydaje sądy i oskarża. Na styl Boznańskiej składa się naturalna swoboda, urok, pieszczota. Styl Muter jest gwałtowny, niewzruszony w swej przemocy, ostry, napięty aż do krzyku, à la Van Gogh ${ }^{74}$.

Czy jednak przeciwieństwo stylistyki mocarnej i dominującej Muter i drżącej i pieszczotliwej Boznańskiej znajdowało odbicie w ich osobowości?

Muter już jako młoda mężatka, uległa urokowi poety Leopolda Staffa. Nawet jeśli ta wielka miłość pozostała niespełniona, to małżeństwo z literatem Michałem Mutermilchem uległo rozkładowi. Choć artystka zajmowała się regularnie synem, to jednak nie mieszkała $\mathrm{z}$ rodziną. W czasie pierwszej wojny światowej zakochała się we francuskim działaczu socjalistycznym, Raymondzie Lefevbre, z którym, po uzyskaniu rozwodu, planowała małżeństwo. Tragiczna śmierć Lefevbre'a w Związku Radzieckim w 1920 roku, w drodze powrotnej z kongresu III Międzynarodówki w Moskwie, głęboko dotknęła artystkę. Załamana, wyjechała z synem na wakacje w 1921 roku na Lazurowe Wybrzeże. Tam zawarła krótkotrwałą znajomość ze słynnym angielskim krytykiem i teoretykiem sztuki, a także malarzem, Rogerem Fry’em. W 1925 roku związała się amitié amoreuse z Rainerem Marią Rilkem, a ich wzruszająca korespondencja trwała aż do śmierci poety w 1926.

W odróżnieniu od Boznańskiej, Muter uprawiała nie tylko malarstwo portretowe, ale także pejzażowe, w którym osiągnęła mistrzostwo. Sławę jednak zdobyła jako portrecistka. Na salonach przed pierwszą wojną światową przedstawiała głównie portrety osobistości polskiej kolonii, np. bliskiego przyjaciela, malarza Leopolda Gottlieba (1904), przyszłego noblisty, pisarza Władysława Reymonta i jego żony (ok. 1907), czynnego w Paryżu krytyka artystycznego Antoniego Potockiego (ok. 1911), czy wreszcie pozującego wcześniej Boznańskiej Henryka Sienkiewicza (1915). Krytyka francuska zauważyła jej talent już w 1904 roku, czego dowodem może być następująca wypowiedź:

Spośród niemal wszystkich kobiet, jakie przybyły do Francji, by studiować sztukę, pani Mutermilch zdecydowanie się wyróżnia. Przyjeżdżając bowiem, żeby uczyć się u naszych mistrzów, przywiozła ze sobą niezbędny bagaż, który pozwala jej faktycznie skorzystać z tych nauk, których uczeń pozbawiony talentu nie potrafiłby zrozumieć. Dlatego pani Mutermilchowa już osiągnęła tak znakomite rezultaty. Jej obrazy podobać się

${ }^{73}$ Por.: H. Zbierzchowski, Z pracowni artystów polskich w Paryżu. Boznańska, Mutermilchowa, Tygodnik Ilustrowany $1910 \mathrm{nr} 40$, s. 804-805; M. Goth, Au Salon de la Nationale. Le portrait, Les Hommes du jour 1913 nr 278.

${ }^{74}$ M. Goth, Au Salon de la Nationale. Le portrait, Les Hommes du jour 1913 nr 278. 
mogą z dwóch powodów: są skomponowane według reguł malarskich i promieniują zdrową i prawdziwą poezją ${ }^{75}$.

Rząd francuski zakupił pierwszą jej pracę, grafikę Zmęczeni, do zbiorów państwowych już w 1910 roku. Potem miały miejsce następne, wspomniane wyżej zakupy. Już przed pierwszą wojną światową Muter portretowała ważne postacie paryskiej sceny artystycznej, jak np. poetę Paula Forta ok. 1905 roku czy meksykańskiego malarza Diego Riverę w 1913 roku. Związek z Lefevbrem pozwolił jej poznać i portretować działaczy intelektualnej lewicy francuskiej, a wśród nich pisarzy Henri Barbusse'a czy Romaina Rollanda, laureata Nagrody Nobla w dziedzinie literatury w 1915 roku. Malowała swoich bliskich, kolegów artystów, muzyków, literatów, polityków, dyplomatów, działaczy, marszandów, arystokratów różnych narodowości ${ }^{76}$. W przeciwieństwie do Boznańskiej organizowała wystawy indywidualne $\mathrm{w}$ galeriach, bywała w artystycznym i intelektualnym świecie, a wyrazem sukcesu finansowego była willa zbudowana dla niej w dzielnicy Montparnasse przez wziętego francuskiego architekta Auguste'a Perreta. Mając bardzo liczne sposobności do prezentacji swoich dzieł Muter zdecydowała się na udział w wystawach o charakterze kobiecym dopiero u szczytu sławy ${ }^{77}$. Nie posłużyła się tego rodzaju okazjami do budowania swojej kariery, jak po części uczyniła to Boznańska. Czy małżeństwo i macierzyństwo przeszkadzało jej w prowadzeniu zawodowej kariery? Odpowiedź na to pytanie nie jest jednoznaczna, bowiem życie artystki było burzliwe. Z pewnością dążyła do ustabilizowanego i trwałego związku z mężczyzną. Los na to nie pozwolił.

Do wspominanych powyżej poważnych osiągnięć doszła samodzielnie, ze stygmatem rozwodu, dotknięta osobistymi nieszczęściami. Światowy kryzys, a potem druga wojna światowa, kiedy to jako Żydówka z pochodzenia, choć przyjęła katolicyzm, musiała się ukrywać, zepchnęły ją z głównego nurtu artystycznego życia. Krucha, drobna Boznańska szła przez życie może z pozoru drobnym, niepewnym krokiem, ale odrzucała konsekwentnie wszystko (i wszystkich), co mogło odwieść ją od wyznaczonego celu, jakim był jej własny zawód. Okazała, monumentalna Mela Muter, idąc uparcie do przodu szukała emocjonalnego oparcia w mężczyznach, nie tylko wypełniając heroicznie i z samozaparciem rolę bolesnej matki, ale realizując się przede wszystkim jako artystka, co sama podkreśliła mówiąc: „nie jestem kobietą, jestem malarzem"78. Zarówno Boznańska, jak i Muter doszły do wyznaczonego celu, jakim było uprawianie trudnego zawodu artysty, samodzielnie, jako kobiety samotne, emancypantki, każda odgrywając tę rolę na swój sposób.

Podsumowując nasze rozważania musimy stwierdzić, że polskie artystki, które zaczęły pojawiać się w Paryżu od lat 80. XIX wieki, stanowiły istotną grupę wśród czynnych tam polskich twórców. W odróżnieniu od mężczyzn nie przyjeżdżały tam na ogół z powodów politycznych. Jednak pojedyncze artystki, sympatyzujące na przełomie XIX i XX wieku z ruchami socjalistycznymi i wolnościowymi, jak np. Maria Mi-

${ }^{75}$ J. d'A., Mme Mütermilchowa, Bruits de Paris 19.06.1904.

${ }^{76}$ Por.: E. Bobrowska, Portret ,szalonych lat”: Mela Muter na międzynarodowej scenie artystycznej Paryża, [w:] Mela Muter. Malarstwo / Peinture, [pod red. M. A. Supruniuka, S. Majocha], Torun 2010

${ }^{77}$ Były to wystawy: „Exposition des «Quelques»”, Galerie des Artistes Modernes, Paryż, 1910; Exposition d'un groupe de femmes peintres, Galerie Bernheim-Jeune, Paryż, 1928; wystawy stowarzyszenia Les Femmes artistes modernes, w których uczestniczyła, podobnie jak Boznańska, w latach 1931-1938; por.: P. Birnbaum, Women Artists in Interwar France; Exposition des femmes artistes de France à Prague, [katalog wystawy], Praha, 1937.

${ }^{78}$ R. Demeurisse, Mela Muter, L'Europe nouvelle 11.07.1931, s. 951. 
recka Szeliga, znalazły tam schronienie. Również przyczyny ekonomiczne nie były tak istotne w przypadku kobiet. Panujący ówcześnie model społeczny nie nakładał na nie konieczności samodzielnego zarabiania na życie, czy utrzymania rodziny. Jak pisze wspomniany wielokrotnie Wacław Gąsiorowski, wyjazdy artystek były najczęściej „sponsorowane” przez ich rodziny. Dopiero specyficzna sytuacja rodzinna, rezygnacja $\mathrm{z}$ małżeństwa (pierwotna, jak to miało miejsce w przypadku Boznańskiej, bądź wtórna w przypadku Meli Muter) i wybór samodzielnej kariery zmuszały je do zarobkowania. Francja, zwłaszcza w okresie kryzysu przełomu lat 20. i 30. XX wieku, jak wskazuje analiza życiorysów zarówno Boznańskiej, jak i Muter, była dla nich trudnym terenem do osiągnięcia odpowiednich dochodów.

Polki przyjeżdżały do stolicy Francji głównie z powodów artystycznych: w celu zdobycia wykształcenia artystycznego bądź zakosztowania atmosfery kulturalnej Paryża, o której zresztą najczęściej mowa w ich wspomnieniach i dziennikach. Na trudne do zdefiniowania pojęcie atmosfery kulturalnej składało się zarówno dziedzictwo kulturalne, jakim miasto dysponowało - jego uroda, zabytki, muzea, jak i ożywiona scena kulturalna — salony, wystawy, galerie, międzynarodowe środowisko artystyczne i intelektualne. Większość Polek przyjeżdżała do Paryża na stosunkowo krótkie pobyty, najczęściej na studia. Pobyty te wiązały się często $\mathrm{z}$ pierwszymi próbami konfrontacji z międzynarodowym środowiskiem artystycznym poprzez udział w salonach i wystawach. Należy podkreślić, że debiut za granicą był dla nich tym łatwiejszy, że miał miejsce z dala od ich własnej grupy odniesienia, odbywał się niejako anonimowo i istniały szanse, że w razie ewentualnego niepowodzenia informacja o nim nie dotrze łatwo do ich własnego środowiska. Rezultatem podróży było rozszerzenie horyzontów zarówno kulturalnych, jak i artystycznych. Trudno więc mówić o innych osiągnięciach studentek, czy świeżych absolwentek poza samym faktem ukończenia studiów i artystycznym debiutem. Warto natomiast przyjrzeć się osiągnięciom tych czterdziestu kobiet, które według naszych badań osiadły we Francji bądź na stałe, bądź na dłuższy pobyt, a którym ten kraj zapewniał w części chociaż równe prawa z mężczyznami, jak możliwość wystawiania na salonach, zdobywania nagród, zakupów państwowych. Innymi słowy, jeśli oprzeć się na tezie Lindy Nochlin, że to system instytucjonalny kreuje emancypantki, to mogły one faktycznie nimi być.

Jednak mimo ogromnego postępu badań nad historią polskich twórców poza granicami kraju, aktualny ich stan wciąż jeszcze nie pozwala na rzetelne podsumowanie karier wszystkich osiadłych w Paryżu artystek. Nie wydaje się prawdą stwierdzenie, że gdyby faktycznie były one znane i uznane, to by się o tym wiedziało (nawiązuję tu nie tylko do słynnego artykułu Nochlin, ale także do znanego francuskiego powiedzenia). Stwierdzenie takie nie bierze pod uwagę specyfiki zjawiska emigracji. Zdobywanie uznania, a następnie zachowanie pamięci o artyście nabierają na obczyźnie zupełnie innych wymiarów. Konieczność adaptacji do obcych warunków, w tym nauczenia się języka oraz kodów społecznych i obyczajowych, obowiązujących w danym kraju, zabierają emigrantom dużo czasu i energii, w tym również energii emocjonalnej. Poradzenie sobie z poczuciem samotności, obcości, inności i braku przynależności do grupy odniesienia jest procesem trudnym i emocjonalnie ,energochłonnym”. Brak oparcia w osiadłej od pokoleń rodzinie i jej relacjach, znajomościach i koneksjach zdecydowanie ogranicza możliwości awansu społecznego i zawodowego. Ograniczone są także ich możliwości materialne: w większości emigranci rozpoczynają od przysłowiowej „łyżki”" ${ }^{\text {"79 }}$. Francja i jej przywiązanie do

${ }^{79}$ Bardzo pouczająca jest w tym względzie stała ekspozycja w muzeum Cité nationale de l'histoire de imigration w Paryżu, gdzie zobaczyć można przedmioty, z jakimi imigranci przybywali do Francji, w tym wzruszające kartonowe walizki. 
tradycji w analizowanym okresie była zdecydowanie inna niż Stany Zjednoczone, gdzie wszyscy do pewnego stopnia byli imigrantami (aczkolwiek i to stwierdzenie jest wielkim uproszczeniem). We Francji talent nie był wyłącznym wystarczającym atutem, żeby się „przebić”, choć niektórzy francuscy historycy imigracji takie właśnie wygłaszają opinie. Jeden z najwybitniejszych historyków imigracji, Ralph Schorr mówiąc o kategorii notabli, siłą rzeczy nielicznych, wśród imigrantów, zalicza do niej bogatych arystokratów, przemysłowców i bogatych kupców, a także pisarzy i artystów, skupionych głównie w Paryżu. Uważa on, że ich integracja nie przedstawiała jakichkolwiek poważniejszych problemów,

ponieważ osoby te, najczęściej dwujęzyczne, którym obce były problemy materialne,

z wyjątkiem niektórych artystów jeszcze nie uznanych, nawiązywały łatwo kontakty

$\mathrm{z}$ francuskimi kolegami i w sposób naturalny wchodziły w społeczeństwo nowej ojczyzny ${ }^{80}$.

Zdaje się jednak, że wniosek ten wysnuty został na podstawie ograniczonej znajomości międzynarodowego środowiska artystycznego Paryża na przełomie XIX i XX wieku, a głównie studium przypadku, a raczej wyjątku Picassa. Już analiza sytuacji Chaima Soutine'a, nie mówiąc o innych artystach imigrantach z kręgu La Ruche czy szerzej tzw. Ecole de Paris, pozwoliłaby na skorygowanie twierdzenia, że wszyscy artyści imigranci szybko uczyli się języka, zdobywali sławę i łatwo integrowali się w odpowiadającym ich aspiracjom środowisku francuskim. Mówiąc o osiągnięciach artystek polskich we Francji, musimy dokładnie zdawać sobie sprawę, że na kwestię kobiecą nakłada się tu jeszcze kwestia emigracji, która wymaga dalszych, intensywnych badań.

\section{SUFFRAGISTS? POLISH FEMALE ARTISTS IN PARIS BETWEEN THE $19^{\mathrm{TH}}$ AND $20^{\text {TH }}$ CENTURY}

The author analyses the question of professional strategies of about 160 Polish female artists who came to Paris from 1890 to 1918 to study and/or to begin or continue their artistic careers. Paris was in full intellectual and economic flowering and could offer them much more than provincial centres of partitioned Poland. A historical and quantitative analysis shows female's involvement in Parisian system of artistic education, salons and official artistic purchase by the Republic of France. The case studies of the careers of two most distinguished Polish female artists in Paris: Olga Boznańska and Mela Muter serve as examples of two different ways leading to a success, both for females, and for emigrants.

KEY WORDS: Feminine art; Polish art between the $19^{\text {th }}$ and $20^{\text {th }}$ century; Polish art abroad; Polish art in Paris; Polish female artists; Olga Boznańska; Mela Muter; Académie Julian; Paris salons.

${ }^{80}$ R. Schorr, Histoire de l'immigration en France de la fin du XIXe siècle à nos jours, Paris 1996, s. 10. 